\title{
Radical right populism
}

Jasper Muis and Tim Immerzeel

VU University Amsterdam, the Netherlands

\begin{abstract}
This article reviews three strands in the scholarship on the populist radical right (PRR) in Western Europe. It first assesses political opportunity explanations for the fortunes of the PRR. Second, it discusses internal supply-side approaches, referring to leadership, organization and ideological positioning. Third, research on the consequences of the rise of these parties and movements is examined: do they constitute a corrective or threat to democracy? The review concludes with future directions for theorizing and research.
\end{abstract}

keywords anti-immigration parties/movements $\diamond$ far right $\diamond$ populism $\diamond$ radical right

\section{Introduction}

One of the key preoccupations of scholars of contemporary politics is the political backlash of social unease about immigration and cultural diversity. In particular, support for populist radical right (PRR) parties and movements has swelled in previous decades, which has triggered extensive political and scholarly debate (Backes and Moreau, 2012). Whether we like it or not, many citizens support parties and movements that promote xenophobia, ethno-nationalism and anti-system populism (Rydgren, 2007).

This review provides an overview and assessment of the scholarship on the PRR in Western European democracies. First, we briefly discuss the definitional debate about what constitutes the PRR family. Second, we review the literature on supply-side explanations for the fortunes of PRR parties and movements. Third, we discuss research on the consequences of the emergence and rise of PRR parties and movements. Do they constitute a corrective or threat to democracy (cf. Mudde and Rovira Kaltwasser, 2012)? There is now a growing literature that tackles this question in an empirical manner (Immerzeel and Pickup, 2015). The review concludes with a discussion of the future directions that theorizing and research could take.

We narrow our scope to the PRR in contemporary
Western European democracies. Nevertheless, the theories, findings and suggestions for future work could also be applicable to comparable cases elsewhere, such as the Tea Party in the United States (Parker and Barreto, 2014; Williamson et al., 2011) and PRR parties and organizations in Eastern Europe (Allen, 2015; Minkenberg, 2015; Pirro, 2015).

Until today a strict labour division seems to divide sociologists from political scientists, with each discipline focusing on the non-electoral and electoral channel, respectively (Rydgren, 2007). Social movement protests have generally been dominated by 'the left', while 'the right' mainly uses the electoral channel to voice its discontent, instead of taking to the street (Hutter, 2014; Van der Meer et al., 2009). Consequently, social movement scholars tend to overlook the most important contemporary actors mobilizing against the consequences of globalization and immigration: the populist radical right (Hutter and Kriesi, 2013). As Caiani et al. (2012: 4) put it: 'while political party studies provide more and increasingly sophisticated analyses of radical right parties, social movement studies ... has been slow to address the "bad side" of social movement activism'. Only when sociologists widen their perspective to the electoral channel, are we able to fully grasp the implications of

\section{Sociopedia.isa}

(C) 2016 The Author(s)

(C) 2016 ISA (Editorial Arrangement of Sociopedia.isa)

Jasper Muis and Tim Immerzeel, 2016, 'Radical right populism', Sociopedia.isa, DOI: $10.1177 / 2056846016121$ 
globalization and large-scale immigration for political contention.

\section{Definitional debate on radical right- wing populism}

Different labels such as 'extreme right' (Arzheimer, 2009; Bale, 2003; Lubbers et al., 2002), 'far right' (Ellinas, 2007; Erk, 2005) and 'populist radical right' (Mudde, 2007) are used interchangeably to refer to the same organizations, such as the French Front National (FN), Austrian Freedom Party (FPÖ) and Flemish Bloc/Flemish Interest (VB). A consensus has emerged that they constitute one single family. According to Mudde's (2007) influential definition, three features characterize this family: nativism, populism and authoritarianism.

The most important common denominator is their nativist stance. This exclusionist, ethno-nationalist notion of citizenship is reflected in the slogan 'own people first' (Betz, 1994; Immerzeel et al., 2016; Rydgren, 2005a). The label 'radical' refers to the non-centrist, outspoken position at the far end of the political spectrum on issues related to immigration and ethnic diversity (Akkerman et al., 2016). Since they strongly hold issue-ownership over immigration issues (Abou-Chadi, 2016) some scholars simply refer to the PRR as anti-immigration parties (Fennema, 1997; Van der Brug et al., 2005).

Second, PRR groups share their populist, antiestablishment rhetoric (Carter, 2005; Ivarsflaten, 2008; Mudde, 2007; Pelinka, 2013). Populism is a communication style or 'thin' ideology that divides society into two homogeneous groups: the 'pure people' and the untrustworthy 'corrupt elite' (Akkerman et al., 2013; Canovan, 1999; Jagers and Walgrave, 2007; Mudde, 2007).

Third, authoritarianism implies stressing themes like law and order and traditional values. Relatedly, PRR groups favour strong leaders who reflect 'the will of the people' (Inglehart and Norris, 2016). However, there is no consistent empirical relationship between authoritarianism and PRR party preference (Dunn, 2015). At least in Scandinavia and the Netherlands, 'new' PRR parties have stressed progressiveness - liberty, women's rights, individualism - against reactionary authoritarian standpoints (Akkerman and Hagelund, 2007; De Koster et al., 2014; Rydgren, 2005b). Moreover, the picture painted of social movement activists is at odds with traits such as conformism or submission to traditional authority (Klandermans and Mayer, 2006)

It is often stated that radical right populism endangers some of the constitutional foundations of liberal democracies: pluralism and the protection of minorities (Abts and Rummens, 2007; Betz, 2004; Mudde, 2007). At the same, however, scholars agree that it distinguishes itself from political extremism, in the sense that PRR supporters and activists respect democracy, whereas extremist groups go beyond the limits of the procedures which define the democratic political processes (Betz and Johnson, 2004; Klandermans and Mayer, 2006; Minkenberg, 2011; Rydgren, 2007).

In a nutshell, substantial progress has been made in three respects. First, scholars have diverted their attention away from trivializing definitional debates about what right-wing radicalism or populism really 'is'. Instead, they have increasingly focused on more informative discussions about theories and hypotheses. Second, scholars increasingly focus on actually measuring the ideological characteristics and policy stances of both PRR and mainstream parties (Eger and Valdez, 2015; Immerzeel et al., 2016; Pauwels, 2011a; Rooduijn and Pauwels, 2011). As a corollary, most scholars have abandoned reasoning in clear-cut categories. A strict 'either-or' logic (Mudde, 2007; Van Kessel, 2015) has been replaced by the argument that populism is more a 'matter of degree' (Gidron and Bonikowski, 2013; Pauwels, 2011a). Likewise, parties can position themselves somewhere on the left-right or cosmopolitan-nativist dimension (Akkerman and Rooduijn, 2015; Van Spanje, 2011a). Nevertheless, for many research questions requiring case selection it is still necessary to delineate which ones deserve the label PRR and which ones not.

\section{Explanations for failures and successes: demand- and supply-side approaches}

Explanations for the rise and fortunes of PRR parties and movements are usually grouped into two approaches: one focusing on grievances and one on political constraints and opportunities. This corresponds with the distinction between demand-side and supply-side factors (Klandermans, 2004; Koopmans et al., 2005; Mudde, 2007; Rydgren, 2007; Van der Brug and Fennema, 2007; Van der Brug et al., 2005). Supply-side factors can be divided into internal factors (De Lange and Art, 2011; Norris, 2005), like organizational characteristics (Art, 2011; De Witte and Klandermans, 2000; Lubbers and Scheepers, 2000) and external factors, such as institutional frameworks and elite responses (Arzheimer and Carter, 2006; Kitschelt and McGann, 1995). External implies that they cannot be controlled by PRR actors themselves (Goodwin, 2006). These two sets of explanations should be 
viewed as complementary, rather than competing theories (Van der Brug and Fennema, 2007). Demand-side explanations are important to understand why the PRR emerged in the first place.

This review focuses on supply-side factors. We will ignore demand-side accounts, because the sociodemographic characteristics and attitudes of radical right supporters have already been extensively investigated and reviewed (Arzheimer, 2012; Inglehart and Norris, 2016; Mudde, 2010; Van der Brug and Fennema, 2007). The findings can be summarized into two general claims. First, protest is not 'unideological', but clearly directed against policies concerning immigration, integration and law and order (Eatwell, 2000; Swyngedouw, 2001). Alternatively, now and then, supporters of PRR groups are somewhat vaguely characterized as irrational and alienated, seemingly unconnected to any particular values, policy preferences or ideology. However, this claim is empirically untenable. Voting for PRR parties is largely motivated by ideological and pragmatic considerations, just like voting for other parties (Van der Brug et al., 2000; Zhirkov, 2014). In a similar vein, Klandermans and Mayer (2006: 267) conclude that radical right activists are socially integrated and appear as 'perfectly normal people' (cf. Blee and Creasap, 2010: 271).

Second, it has become clear that a complete and satisfying explanation for PRR popularity and presence in the political system needs to go beyond the demand-side model. It fails to explain short-term fluctuations within countries or large differences between otherwise mostly similar countries (Coffé, 2005). Reviewing social structure and demand explanations, Norris (2005: 14) states that 'their failure to provide an overall explanation is clear from even a simple glance at the clear contrasts in radicalright fortunes found between neighbouring states which appear to share similar cultural values, postindustrial service-sector economies, and comparable institutions of representative democracy'. For example, Austria, where the FPÖ has enjoyed considerable electoral successes, is hardly more deprived than Germany, where the PRR is weak. Similarly, comparing the divergent fortunes of the Walloon Front National and Flemish VB, it is hard to imagine that immigration and unemployment have created significantly larger electoral demands for the radical right in Flanders compared to the Walloon region (Arzheimer, 2012).

\section{The external supply-side: political constraints and opportunities}

According to external supply-side explanations, successful mobilization is first and foremost the result of constraints and opportunities that the political and institutional context offers. Examples of such external characteristics are the electoral system, the 'political space' (or 'ideological room') left open by political competitors, responses from established/mainstream parties (i.e. any party that is not considered as part of the PRR) or splits among the political elite, most notably on the issue of the multicultural society. Several researchers have convincingly shown that such factors matter, both for the action repertoire that PRR actors adopt (Caiani and Borri, 2013; Koopmans et al., 2005) and their electoral performances (Arzheimer, 2009; Arzheimer and Carter, 2006; Carter, 2005; Lubbers et al., 2002; Norris, 2005; Van der Brug et al., 2005).

\section{Institutional framework}

Political-institutional variables generally show not much variation. These deeply embedded or fixed opportunities are obviously most useful for comparing different national settings, explaining country differences in PRR success. Scholarship that traces the impact of the institutional framework include works that assess whether the level of federalism and the electoral system affect the popularity of the PRR (Carter, 2002; Hakhverdian and Koop, 2007; Swank and Betz, 2003; Veugelers and Magnan, 2005). According to Kitschelt (2007: 1193), a review of institutional accounts of PRR party strength is 'a frustrating business'. He notes that 'although there are plenty of studies that test for institutional effects, they tend to be theoretically misspecified and empirically not capturing the configuration of institutional rules that should make a difference for electoral support of such parties'. Moreover, in short, the general lesson is that the impact is modest.

Several studies have indicated that more proportional electoral systems are conducive to the entrance or success of new parties (Tavits, 2006), but findings regarding radical parties in particular have been mixed (Carter, 2005; Golder, 2003; Jackman and Volpert, 1996; Norris, 2005; Van der Brug et al., 2005). Electoral thresholds may induce potential radical right voters to support mainstream parties when they perceive their favourite party to be too weak to overcome the barrier to entry (Givens, 2005). Clearly, the institutional configuration most unfavourable for newcomers exists in Britain (Kitschelt, 2007). That the British radical right has 'failed' is often attributed to the majoritarian 
electoral system as primary reason (John and Margetts, 2009).

\section{Political space}

In addition to the institutional framework, the emergence and rise of the PRR is affected by the positioning of the political parties within the policy space (Kitschelt and McGann, 1995). Political space refers to the degree to which mainstream parties (or moderate-right parties in particular) already occupy the electoral terrain of the populist right. For that matter, the positions of the established parties shape the electoral fortunes of any 'niche' party (Meguid, 2005). When they ideologically converge, they leave a 'gap' in the electoral market, which can potentially be exploited by challengers. Kriesi et al. (2006, 2012) argue that where established parties follow a moderate course in favour of the 'winners' of globalization, they provide an opportunity for the creation of parties that mobilize the 'losers'. Several studies indeed found that ideological convergence between mainstream parties benefited the entrance or success of radical new parties (Arzheimer and Carter, 2006; Carter, 2005; Norris, 2005; but see Veugelers and Magnan, 2005).

We need to distinguish issue positions from issue salience. Therefore, mainstream parties have three strategies at their disposal: remain silent on the particular issue (dismissive), distance itself from populist anti-immigrant viewpoints (adversarial), or adopt a similar position (accommodative). Meguid (2008) argues that issue salience will only enhance PRR support when mainstream parties declare hostility toward the niche party's policy position. If mainstream parties employ accommodative tactics, electoral support for PRR contenders will diminish. Many scholars similarly argue that the PRR loses out when mainstream parties adopt restrictive positions on immigration (Arzheimer and Carter, 2006; Kitschelt and McGann, 1995). This strategy may however backfire (Bale, 2003). Eatwell (2000: 423) for instance observed that mainstream parties 'play with fire' when they adopt anti-immigrant themes because it legitimizes the agenda of the PRR.

Political space is measured in different ways, for different time periods. Partly due to this variation, the results of studies on the effect of the political agenda of other parties on the popularity of PRR challengers show a mixed picture. For instance, using Eurobarometer surveys (1980-2002) and party statements on internationalism, multiculturalism, national lifestyle and law and order from the Comparative Manifestos Project (CMP), Arzheimer (2009; cf. Arzheimer and Carter, 2006) found that the ideological position of the established major moderate-right party (labelled 'toughness') had no significant effect on cross-national differences in the amount of support for the PRR. On the other hand, saliency, the relative amount of these statements in the manifestos of all established parties (ignoring the direction of the statements), had a positive impact on levels of PRR support.

In contrast, Van der Brug et al. (2005) found that PRR parties are more successful when the moderateright occupies a more centrist position on a general left-right scale (it is unclear what a position on this scale exactly signifies). They relied on the European Elections Studies data (1989-1999) and use respondents' perceptions to measure party positions. And in this case, the extent to which the anti-immigration parties' mainstream competitor emphasized the core issue of the radical right was not significant, although they measured saliency similarly as Arzheimer (using the CMP data) by selecting the issues crime, negative references to multiculturalism and positive references to 'the national way of life'.

\section{The role of the media environment}

The above-mentioned contradiction could perhaps be solved when we complement the political space approach with the notion that opportunities and constraints need to become visible through public statements in order to become relevant (Koopmans and Olzak, 2004). Political contention increasingly consists of a battle over attention and approval in the public debate (Castells, 1997). Populist movements rely heavily on the media, and the controversial, tabloid-style language of its leaders flourishes well in a 'media logic' in which newsworthiness is increasingly based on conflicts and scandals (Aalberg et al., 2016).

The role of the public debate corresponds better with an externalist 'opportunity' view than with an internalist approach because gaining access to the mass media is largely beyond the control of PRR challengers themselves - gatekeepers and established political actors let them appear on stage. For smaller or marginal parties, the media are arguably more important than for established major parties, because they often lack sufficient organizational and financial means to get their message across to potential adherents. Like social movements, they need the media far more than that the media need them (Gamson and Wolfsfeld, 1993).

There are many indications that the 'media factor' shapes the fortunes of PRR groups. For example, the French FN made its electoral breakthrough in 1984 only after Jean-Marie Le Pen was given access to state television (Eatwell, 2005). His popularity increased remarkably after he appeared on a popular talk show called The Hour of Truth: voter intentions for FN doubled from 3.5\% to 7\% (Ellinas, 2009; 
Ignazi, 2003). Another example is the 'pro-Haider line' (i.e. favourable coverage for the FPÖ) of the Kronen Zeitung, Austria's largest newspaper, between 1986 and 2000 (Art, 2007).

Media-related independent variables can be grouped into (1) media attention for issues associated with the PRR and (2) attention for PRR actors. Regarding the first, the empirical findings are inconclusive. On the one hand, news coverage on the issues of immigration and integration, and law and order enhances the electoral attractiveness of PRR parties (Boomgaarden and Vliegenthart, 2007; Plasser and Ulram, 2003; Walgrave and De Swert, 2004). This finding confirms the agenda-setting hypothesis, which holds that issues that appear frequently in the news tend to become the issues that voters deem important. Combined with the idea that the electorate will support the most credible proponent of a particular issue, it follows that media publicity for issues that are 'owned' by anti-immigration parties enhances their electoral attractiveness (Muis, 2015).

Several researchers have also investigated the effect of news coverage on PRR actors (Lubbers, 2001; Lubbers and Scheepers, 2001; Muis, 2015; Vliegenthart et al., 2012). Scholars have differentiated between coverage for populist right speakers and for responses of other actors, between positive and negative coverage (Bos et al., 2010; Koopmans and Muis, 2009; Muis, 2015), and between the visibility of leaders and parties (Vliegenthart et al., 2012).

Stewart et al. (2003: 236) argue that any media coverage gives advantage to political figures since it enhances their visibility and furthers their goals, by producing some kind of public legitimation'. Research has shown that PRR leaders have clearly profited from media prominence, like Pim Fortuyn (Koopmans and Muis, 2009) and Geert Wilders (Bos et al., 2010). Vliegenthart et al. (2012) find that party visibility enhanced electoral support for five of the six anti-immigrant parties they investigated, namely VB, Party for Freedom (PVV), Republikaner, National Democratic Party for Germany (NPD) and German People's Union (DVU). The Dutch Centre Democrats (CD) was the one exception.

Muis's (2015) study on the CD showed two opposite effects: negative publicity was electorally harmful, but at the same time increased media visibility. The party did not increase its popularity when it achieved media access because the outright racist claims of its leader Hans Janmaat provoked harsh criticism. But when trying to attract as much attention as possible and gaining an influential voice in the debate, 'any publicity is good publicity'. Apparently, both news on support and on criticism gives actors newsworthiness and greater opportuni- ties to put their own viewpoints in the spotlight.

The difficulty is thus to find the right balance between enhancing newsworthiness and electoral credibility. Populist leaders face a trade-off between 'being somewhat unusual and provocative ... (in order to guarantee newsworthiness and therefore prominence)' and being 'taken seriously as a party' (Bos et al., 2010: 143).

To conclude, media effects are conditional on which stance is promoted. Future studies could be enriched by devoting more attention to adaptation and 'upward dynamics'. For instance, Clarke et al. (2016) argue that an escalation of volatility in the United Kingdom Independence Party (UKIP) increased publicity for the party, which in turn prompted further electoral growth. Media visibility and attracting additional adherents seem to reinforce each other (Koopmans and Muis, 2009; but see Van der Pas et al., 2013).

\section{Repression, cordon sanitaire}

This brings us to the role of repression and legal measures, such as bans and prosecutions. A similar logic applies here: the effect of repression is conditional. Its effects may depend on the politician or group targeted and the situation they are in. Another relevant factors is the nature of the statements in question (Van Spanje and De Vreese, 2015). For instance, the hate-speech charges pressed on Geert Wilders in 2009 considerably boosted electoral support for his party (Van Spanje and De Vreese, 2015). Wilders had already established himself as a powerful politician by the time it was decided that he was to stand trial. He had already obtained much legitimacy and media visibility and his party already held nine seats in the national parliament.

The impact of prosecution is very different for politicians and groups on the fringe. When movement activists are faced with legal and social sanctions (e.g. public disapproval and exclusion), protesting is a costly business and the ability to attract a wider support-base is undermined.

Countries also differ significantly in laws regulating the Internet, and thus how favourable a national context is for the online activities of radical rightwing groups (Caiani and Parenti, 2013). In addition to legal measures, PRR parties sometimes suffer political exclusion in the form of a refusal by other parties to cooperate with them (a so-called cordon sanitaire) (Akkerman et al., 2016). It is however not clear whether it is an effective strategy if the purpose is to undermine electoral support. Results on the effects of exclusion on electoral outcomes of PRR parties are mixed (Pauwels, 2011b; Van Spanje and Van der Brug, 2009). We will return to the exclusion-radicalization thesis, which holds that excluded 
parties will radicalize their ideological stances (Akkerman et al., 2016).

\section{Internal supply-side factors: characteristics of the PRR}

From an internal supply-side perspective, PRR parties and movements are largely 'masters of their own success' (Carter, 2005; Goodwin, 2006; Mudde, 2007). We cannot reduce them to the passive consequences of socio-economic processes and external political conditions, but should treat them as shapers of their own fates. A successful PRR party employs strategic flexibility in order to exploit whatever favourable circumstances arise (Ignazi, 2003). We can distinguish two factors: ideology and organizational structure, including leadership (Carter, 2005; Goodwin, 2006).

\section{The role of ideology}

What parties most importantly can achieve through their own actions is to find a beneficial position in the policy space. Kitschelt and McGann (1995) claimed that the ideological 'winning formula' combines culturally exclusionist/authoritarian positions with liberal pro-market positions on socio-economic policies. However, the position that is said to make the PRR successful has changed over time (De Lange, 2007; Kitschelt, 2004). The PRR has abandoned right-wing economic stances (Eger and Valdez, 2015) and adopted protectionism (Rydgren, 2013) and 'welfare chauvinism', the view that social benefits should be restricted to natives (Andersen and Bjørklund, 1990; Oesch, 2008; Schumacher and Van Kersbergen, 2016).

Most PRR groups are comparable because they share the nativist stance as their unique selling point. However, at the same time they are distinct in their ideological character and framing, and these differences have crucial consequences in terms of the parties' fortunes. The 'master frame' (combining nativism with populism) needs to be modified to the particular national political and cultural context in which these groups operate (Caiani and Della Porta, 2011; Rydgren, 2005b).

Carter (2005), who included not only PRR, but also non-democratic parties, demonstrated a relation between the type of ideology parties employ and their success: more extreme parties are less successful. She encountered some notable exceptions. The Dutch CD was for instance a deviant case: most of the party's ideological counterparts have flourished, like in Austria (FPÖ), France (FN) and Belgium (VB). The ideological character does not only have direct effects on the fortunes of parties, it also inter- acts with other explanatory factors. Golder (2003) found that increasing unemployment and high levels of immigration only yield more electoral success for the group of radical right parties he labelled 'populist', but not for the ones that were labelled as 'neofascist'. Despite these two examples, to date, research that elaborates the internal supply-side notion that one's ideological stance crucially matters, and systematically tests effects of PRR parties' platforms is relatively scarce (for another exception see Kitschelt and McGann, 1995); the focus on opportunities and demand-side factors has clearly prevailed. Instead of figuring as an explanatory factor, party ideology has played a more dominant role in delimiting the dependent variable.

The studies of Carter (2005) and Golder (2003) cited above illustrate a remarkable weakness that has hampered a fruitful elaboration of explanations based on ideological positioning: Carter considers the $\mathrm{CD}$ as similar in ideological outlook to, for instance, the FPÖ, FN and VB, based on an extensive typology that (in theory) distinguishes no fewer than 16 mutually exclusive sub-types within the family of the radical right; in contrast, according to a straightforward dichotomy outlined by Golder, the $\mathrm{CD}$ is different from these three other radical right parties.

Future work in this field could make progress in several ways. First, it could benefit from studies on the political space provided by the mainstream parties, which has led to much more fruitful research and findings (Arzheimer, 2009; Arzheimer and Carter, 2006; Koopmans et al., 2005; Meguid, 2005; Norris, 2005). As we discussed earlier, in contrast to party-centric explanations, the ideological niche available on the electoral market is usually measured with continuous variables.

Second, more sophisticated behavioural models of party strategies are useful (Kitschelt, 2007). In order to explain success, we should not only try to identify a certain policy package that 'works' beneficially. In addition, we need to establish a deeper explanation by providing the mechanism by which parties are able or inclined to arrive at successful positions over time. Only a few accounts of far-right populism clearly explicate why or how successful populist leaders were able to find a 'successful position' and why most other attempts of politicians failed to do so (Muis and Scholte, 2013).

\section{Organizational arguments and leadership}

Besides ideology, organizational characteristics such as a lack of financial resources, appealing leadership and shortfall of active membership have frequently been proposed as pivotal factors for the success or failure of PRR parties and movements (Art, 2011). 
Lack of coherence of party organizations and intraparty conflicts have often hampered PRR parties (Heinisch and Mazzoleni, 2016).

However, organization characteristics that are supposedly beneficial or indispensable often do not seem to be relevant in order to account for the impressive performance of populist challengers. As pointed out earlier, many leaders rely almost entirely on media attention, and successful trajectories often illustrate how media visibility can compensate for organizational weaknesses (Ellinas, 2009; Mazzoleni, 2008). The growth of active membership and the building and improvement of an organization often lag behind success, instead of the other way around: media attention and electoral support are first successfully mobilized, then organizational and financial resources follow. In a review article on party organization effects, Ellinas (2009: 219) states that organizational arguments 'would need to carefully trace the evolution of party organisations to establish the direction of causality'. His evidence from the French FN indicates that organizational growth seems to be rather the consequence than the cause of electoral party success, especially during the earlier stages of development. In a similar vein, De Witte and Klandermans (2000) identified a 'circle of organisational weakness': weak organizations (like the Dutch CD) remained weak, whereas, in contrast, strong organizations (like the Flemish Bloc in Belgium) became stronger over time. In sum, organizational resources seem often both a cause and a result of success. As a genuinely 'independent variable', organizational strength might be more important to explain the persistence of parties after their initial breakthrough (Ellinas, 2007, 2009).

De Witte and Klandermans (2000) argued that charismatic leaders who are able to maintain peace in an organization can instigate an upward spiral of organizational strength (cf. Klandermans and Mayer, 2006). Charismatic leadership is indeed a prominent supply-side explanation in the academic literature (Deiwiks, 2009; Eatwell, 2005; Lubbers et al., 2002).

However, the charisma explanation suffers from the tendency of circular reasoning (Van der Brug and Mughan, 2007; Van der Brug et al., 2005). Charisma is a legitimization for those who appear to be the 'heroes of a war' and can just as suddenly vanish as it appears. If a leader is unsuccessful, or if the leadership fails to benefit the followers, charismatic authority can quickly disappear. Max Weber (1947 [1921]) illustrates this by noting that even Chinese monarchs could sometimes lose their status as 'sons of heaven' because of misfortune, such as defeat in war, floods or drought. To conclude, outstanding charismatic appeal is thus better seen as an emergent situational characteristic, rather than attributed to the skills and personality of the leader concerned.

\section{Consequences of PRR party and movement success}

In addition to the causes of PRR fortunes, more recently, scholars have increasingly formulated and tested hypotheses on the consequences of the emergence and rise of PRR parties and movements (Mudde, 2013; Rosanvallon, 2008). Some scholars have claimed that the PRR constitutes a serious threat to democracy because it emphasizes a homogeneous voice - the 'voice of the people' - and threatens the rights and protection of minority groups (Abts and Rummens, 2007; Mudde, 2007).

Others have noted that PRR parties, or populist and Eurosceptic parties more generally, actually correct democratic deficiencies by speaking to a large group of citizens disillusioned with mainstream politicians (Mudde and Rovira Kaltwasser, 2012; Usherwood and Startin, 2013). Citizens feel that there is someone who has 'listened to their grievances' (Ivarsflaten, 2008) and enables them to become passionately, rather than rationally, involved in politics (Mouffe, 2005).

Although the debate about whether the PRR constitutes a threat or corrective to democracy is often a normative one, the question of whether there is a relationship between PRR successes and various outcomes associated with the quality of democracy (such as voter turnout) can be empirically tested (Immerzeel, 2015). Therefore, and related to the observation that the PRR has assumed more stable positions within the party and electoral system (De Lange, 2012; Zaslove, 2008), the last decade has witnessed a steady rise in scholars studying the impact of PRR success on several domains, including the party system (Mudde, 2014) and media debate (Rooduijn, 2014). We restrict ourselves here to the literature on the impact on policies, on PRR groups themselves and on the public.

\section{Policies and mainstream party positions}

Given the PRR's alleged threatening effect on the position and rights of immigrants, it comes as no surprise that scholars paid attention to the extent to which the PRR was successful in implementing policies derived from its nativist, anti-immigration ideology. Scholars have investigated whether governments that included members of the PRR introduced tougher policies on immigration and integration (Akkerman, 2012; Heinisch, 2003; Luther, 2011; Zaslove, 2004). These studies generally find no or a limited impact of the PRR on the policies 
implemented. For instance, Akkerman (2012) concludes on the basis of a quantitative analysis comparing the immigration and integration output of 27 cabinets of varying composition in nine countries (1996-2010) that when the PRR is in office, cabinets generally introduce stricter immigration and integration legislation than centre(-left) cabinets. Yet, centre-right cabinets that do not include a PRR do not differ in terms of strictness of immigration policy from those including a PRR. She notes that the difficulties these parties face in adapting to public office seriously hinder their effectiveness to implement stricter policies (Akkerman, 2012; cf. Van Spanje, 2011b). The finding of Zaslove (2008) that the Austrian Freedom Party and Italian Lega Nord (LN) have been instrumental in passing more restrictive immigration policy may thus be more due to the performance of the conservative mainstream parties that cooperate with them than because of the performance of the PRR itself (cf. Heinisch, 2003).

Although little evidence is thus found for a direct impact of the PRR on policy outcome, the PRR could influence policy making indirectly, via its impact on other parties' positions (Schain, 2006). As such, scholars have investigated whether the PRR's success influences the policy positions on immigration, multiculturalism, populism, law and order, and more style-related issues, such as anti-establishment rhetoric (Bale, 2003; Bale et al., 2010; Han, 2014; Immerzeel et al., 2016; Rooduijn et al., 2014; Van Spanje, 2010; Williams, 2006). The argument is simple and revolves around electoral returns. As for instance Yilmaz (2012: 376) claims, 'the mainstream right [has] cynically adopted the cultural focus on immigration in part to recapture the anti-immigrant, anti-Muslim animosity that brought the populist farright electoral gains'. A similar vote-seeking logic explains why the mainstream left is paralysed: 'rather than articulating their own vision for the future of the nation (or Europe), they have quietly accepted the basic premise of the Islamophobic/xenophobic perspective in order to keep their constituency from being attracted to the extreme right'. What about the empirical proof for such claims?

To study these effects of the PRR, scholars used either expert surveys, where colleagues are asked to rate all political parties in a country on typical issues (e.g. Hooghe et al., 2010; Immerzeel et al., 2011; Van Spanje, 2010), or the salience of typical PRR issues in the party programmes summarized in the Comparative Manifesto Project (CMP) (e.g. Alonso and Da Fonseca, 2012; Hooghe et al., 2010). Akkerman (2015) used a more fine-grained manifesto content analysis (1989-2011), since the CMP data lack sufficient detail on immigration and integration issues.
The results of these studies can be easily summarized: the PRR affects the stances of mainstream parties on immigration and integration issues, but not on other issues. Based on various expert surveys, Van Spanje (2010) concluded that, in general, all other political parties have become more restrictive with respect to immigration and integration due to the PRR's success. Using manifesto data, Han (2014) and Akkerman (2015) found similar effects. More specifically, Akkerman (2015) finds that it was mainly Liberals who were tempted to co-opt far-right positions while Social Democrats are not affected at all - or at least their reaction is far from uniform (Bale et al., 2010) - and Han (2014) shows that leftwing parties only become less multicultural 'when the opinion of party supporters on foreigners becomes more negative or when the parties lost more votes in the previous election than their opponent right-wing mainstream parties did' (Han, 2014: 1).

With regard to other issues, such as populism and law and order, mainstream parties seem to hold to their original ideological position (Bale et al., 2010). On the basis of manifesto data (Rooduijn et al., 2014) and expert surveys (Immerzeel et al., 2016), scholars do not find that mainstream parties have become more populist and authoritarian.

Hence, there is evidence that the PRRs have an indirect, but modest influence on policy outcomes. This impact of the PRR on policy positions is generally limited to the issue of immigration and integration (Mudde, 2013). Specifically mainstream right-wing parties employ a convergence strategy that puts them ideologically closer to the PRR (Meguid, 2005; Williams, 2006). However, mainstream right parties are often inclined to move toward stricter immigration policy anyway, independently of PRR successes (Akkerman, 2015; Alonso and Da Fonseca, 2012; Bale, 2003). This conclusion also emerges from case studies, such as the UK (Bale, 2013), France (Godin, 2013) and the Netherlands (Van Heerden et al., 2014).

\section{Consequence for PRR parties/movements}

There is also a growing scholarship on how successes of the PRR affect these groups themselves. Most importantly, what effect does the inclusion into a governing coalition have on parties, both in terms of their ideological positions and their electoral success (Akkerman and De Lange, 2012; Akkerman and Rooduijn, 2015; Albertazzi and McDonnell, 2015; Van Spanje, 2011b)? Heinisch (2003) argued that because of their ideology, right-wing populist parties thrive in opposition, but have trouble with actually participating in a government. He claims that governing leads to more moderate positions and hence to electoral losses. 
However, there is no consensus regarding the effect of taking up government responsibility on the ideological positions and electoral success of the PRR. Although there are several case studies, systematic tests of the so-called inclusion-moderation thesis are scarce (Akkerman et al., 2016). Observers have generalized too much from just two prominent cases of failures, the Dutch List Pim Fortuyn (LPF) and the Austrian FPÖ (Mudde, 2013).

Albertazzi and McDonnell $(2010,2015)$ dismiss the received wisdom that populist parties have inherent problems with assuming power. Their case studies of three populist parties in Italy and Switzerland - Popolo della Libertà (PDL), LN and Schweizerische Volkspartei (SVP) - show that PRR parties can thrive and hold on to their radical positions when they take up government responsibility (cf. Frölich-Steffen and Rensmann, 2007). Likewise, Mudde (2013: 15) disagrees with the dominant strain in the populism literature that argues that populist parties are destined for success in opposition and failure in government'. PRR can parties can keep 'one foot in and one foot out' of government (Albertazzi and McDonnell, 2005). They will uphold their oppositional image, by using radical rhetoric and pushing for radical policies, rather than run the risk of being perceived as a 'normal' governmental party and part of 'the corrupt elite'. Based on manifesto coding, Akkerman and Rooduijn (2015) found that none of the 'nonostracized' parties in their study - the Swiss SVP, Austrian FPÖ and Alliance for the Future of Austria (BZÖ), Italian LN, Dutch LPF and Danish People's Party (DF) - became more moderate except the Dutch PVV: its degree of radicalism strongly decreased between 2010 and 2012.

Overall, there is no indication that radical rightwing populist parties are becoming less radical and more 'mainstream' (Akkerman et al., 2016). However, since only a limited amount of parties actually took office, it remains to be seen whether the costs of government are relatively higher for populists.

\section{Citizens' attitudes and behaviour}

Third, the PRR's emergence and success might have consequences at the individual level. Citizens could be affected in the sense that they attach more importance to certain issues, shift their views toward more anti-immigration and authoritarian positions, and change their political behaviour (Andersen and Evans, 2003; Bohman, 2011; Braun, 2011; Dunn and Singh, 2011; Immerzeel, 2015; Ivarsflaten, 2005; Semyonov et al., 2006; Sprague-Jones, 2011; Van der Brug, 2003; Wilkes et al., 2007). PRR groups can make some issues more salient (Bale,
2003; Ivarsflaten, 2005) and trigger politically disengaged people to become actively or passionately involved in politics (Jansen, 2011; Mouffe, 2005).

Studies on the impact of PRR success on immigration attitudes provide a mixed picture (Dunn and Singh, 2011; Semyonov et al., 2006; Sprague-Jones, 2011). Some conclude that successful and highly visible PRR parties can undermine support for multiculturalism (Bohman, 2011), whereas others find no effects of radical right representation on tolerance among European populations. An extensive recent study, based on European Social Survey data (2002-2012), showed that PRR parties have not driven anti-immigration attitudes in Europe (Bohman and Hjerm, 2016). The main difficulty is the lack of longitudinal studies, modelling the attitudinal consequences of PRR success over time. Evidence based on German and Dutch panel data showed that perceptions of threatened group interests precipitate rather than follow citizens' preferences for PRR parties (Berning and Schlueter, 2016).

Regarding political involvement and trust, one might expect that PRR parties foster voter turnout because they are passionate mobilizers that fulfil a watchdog function and reintroduce electoral competition (Franklin, 2004). For instance, Fallend (2012) concludes that the Austrian FPÖ addressed issues neglected by other parties, such as immigration and integration. Accordingly, over the period 1996-2001, the party gave voice to an apolitical part of the electorate, who increasingly felt that politicians listened to them. Likewise, De Lange and Akkerman (2012) showed that since 1997, political trust and satisfaction with democracy in Belgium have increased with the rise of the VB. However, based on a Dutch six-wave panel study (2008-2013), Rooduijn et al. (2016) find that the popularity of populist parties fuels political discontent, rather than dampens it (cf. Van der Brug, 2003).

De Lange and Akkerman (2012) found that in Belgium electoral turnout numbers have decreased, whereas the VB has become more popular, which seems to contradict the idea that the PRR attracts disengaged people. In the same vein, based on an analysis of 33 European countries in the period 2002-2012, Immerzeel and Pickup (2015) find there is no general positive influence of the PRR's popularity on electoral turnout. Yet, the Western European PRR encourages some social groups to turn out for national elections. These groups are, however, people who are actually repelled by them: the more highly educated and politically interested are more inclined to 'keep the rascals out'. To conclude, to speak of the PRR as 'corrective of 
democracy' is - in terms of increasing electoral turnout or increasing political satisfaction - a misunderstanding.

Another interesting question is how institutionalized and non-institutionalized forms of political participation are related. Hutter (2014) finds that the more successful the populist radical right is in electoral terms, the more it tends to abstain from protest activities. In a similar vein, access to political power in a number of Western European countries over the past years might have contributed to less right-wing violence (Ravndal, 2016). Koopmans' (1996) crossnational comparison shows an inverse relation between the success of PRR parties and the incidence of racist violence. Hence, we can conclude that the electoral channel effectively substitutes for street activity and violence (cf. Braun and Koopmans, 2010).

The action repertoire of the PRR thus depends on the political space made available by mainstream parties for far-right mobilization (Giugni et al., 2005). Most European countries have strong PRR parties. But particularly in the United Kingdom and Germany, xenophobic sentiments can hardly be canalized through the electoral channel. It therefore should perhaps not come as a surprise that both countries have experiences with large-scale street movements. Several scholars have interpreted the rise of the English Defence League (EDL) and Britain First as corollary of the decay of the British National Party (BNP) (Alessio and Meredith, 2014; Allen, 2014). The EDL 'offered a more attractive and confrontational alternative to perennial failure at the ballot box' (Ford and Goodwin, 2014: 8). The movement hereby relied heavily on social media to get its message across and recruit supporters (Busher, 2013).

In sum, a weak or fragmented party sector corresponds with a strong movement sector or environment of violence (Minkenberg, 2011). It remains to be seen whether UKIP (in the UK) and Alternative for Germany (AfD) will change this picture in the future. Patzelt and Klose (2016) conclude that the number of Pegida protesters has shrunk since the AfD has increasingly succeeded to put their grievances on the political agenda. Although several AfD politicians have distanced themselves from Pegida (Geiges et al., 2015), a survey showed that 57\% of the Pegida demonstrators in Dresden would vote for AfD, and only about $4-5 \%$ for NPD (Reuband, 2015).

\section{Future directions: how to proceed?}

We conclude this review with a discussion of possible avenues for future research. Although the scholarship on this topic has become a 'minor industry' (Arzheimer, 2012: 35), there are important gaps and opportunities. Concerning research questions, scholars need to pay more attention to the temporal dimension of political contention. Since Minkenberg (2000: 170) observed that 'serious comparative scholarship on the radical right is still in its infancy', cross-national comparisons have become commonplace. Remarkably, however, comparisons in time are still scarce (Ellinas, 2007; Kitschelt, 2007). A dynamic view would address the argument that explanations for and consequences of PRR parties and movements may change during their trajectory.

For instance, before groups pass the 'threshold of relevance' (Carter, 2005; Ellinas, 2007) - i.e. are big enough to matter - organizational attributes might have no effect on their performance. And once populist outsiders have established themselves as strong and credible alternatives, traditional parties may not win back electoral support if they adopt similar agendas (Van Kessel, 2015). Likewise, the impact of taking up government responsibility depends on how long parties exist and whether they have institutionalized (De Lange and Art, 2011).

Cross-national comparisons have focused mainly on the PRR's electoral strength. The strength of social movements and the interplay between movements and parties have received relatively little attention. Except for Germany, there are few systematic comparative studies of the non-party sector of the PRR (Hutter, 2014; Minkenberg, 2005, 2011). Individual-level research is needed on the question whether the electoral channel effectively substitutes for street activity, not only on the macro level (Hutter, 2014; Koopmans, 1996). To what extent do people refrain from using non-parliamentary means to voice their grievances about multiculturalism and immigration, due to electoral successes and/or government inclusion of PRR parties? Do extremist activists perceive voting as a credible alternative option? Minkenberg (2011) points out that supporters of PRR parties do not usually overlap with perpetrators of racist violence. Again, a dynamic perspective is important: over time, movements can turn into political parties, and parties can engage in street demonstrations when they face political obstruction.

This brings us to future avenues for theoretical progress. Both PRR actors and its competitors/opponents can adjust their action repertoire and ideology 
over time, which is insufficiently addressed by static, spatial comparisons. Future scholarship could theorize more about two key components that stem from such an evolutionary perspective on parties and movements: feedback and learning. Actors continually adapt to what has gone before and respond to what other agents are doing. These ingredients make political contention a so-called 'complex adaptive system' (Laver and Sergenti, 2012). A fruitful tool to map out dynamic interactions of adaptive individuals is agent-based modelling, but applications in the PRR literature are scarce.

In terms of confronting theories with empirical evidence, future studies could be enriched by greater attention to PRR parties and movements' presence on the Internet. The current debate on the role of the Internet is characterized by much theoretical speculation; we know little about how these groups use the Internet for political communication and mobilization (Caiani and Parenti, 2013). To date, to assess where PRR groups stand, scholars often rely on manifestos (Akkerman et al., 2016; Eger and Valdez, 2015), expert surveys (Immerzeel et al., 2016) and traditional media outlets (Bos and Brants, 2014; Kriesi et al., 2008).

Few citizens actually read party manifestos. Most people perceive politics by what they read in the media instead (Kriesi et al., 2008). Obviously, using mass media also has a significant drawback, since coverage might be biased (Helbling and Tresch, 2011). These caveats could be overcome by relying on sources that are widely consumed by citizens and controlled by PRR parties and movements themselves, such as Facebook pages (Arzheimer, 2015a) or tweets (Van Kessel and Castelein, 2016).

Social media material could also enrich our understanding of supporters and sympathizers, in addition to surveys or interviews. For instance, Arzheimer (2015a, 2015b) concludes that the German AfD does not qualify as either nativist or populist, but statements of Facebook fans hint at more radical currents among supporters and rankand-file members. The topics that people devote most attention to (Islam and immigration) are hardly mentioned in AfD's own posts.

\section{Annotated further reading}

\section{Review articles on explanations for emergence and rise:}

Arzheimer K (2012) Electoral sociology: Who votes for the extreme right and why - and when? In: Backes U and Moreau P (eds) The Extreme Right in Europe: Current Trends and Perspectives. Göttingen:
Vandenhoeck and Ruprecht, pp. 35-50.

Ellinas AA (2007) Phased out. Far right parties in Western Europe. Comparative Politics 39(3): 353-371.

Kitschelt H (2007) Growth and persistence of the radical right in postindustrial democracies: Advances and challenges in comparative research. West European Politics 30(5): 1176-1206.

Rydgren J (2007) The sociology of the radical right. Annual Review of Sociology 33: 241-262.

Van der Brug W and Fennema M (2007) What causes people to vote for a radical-right party? A review of recent work. International Journal of Public Opinion Research 19(4): 474-487.

\section{Review articles that also address the} consequences of emergence and rise:

Betz H-G (2004) Exclusionary populism in Western Europe in the 1990s and beyond: A threat to democracy and civil rights? Identities, Conflict and Cohesion Programme Paper No. 9, United Nations Research Institute for Social Development.

Mudde C (2013) The 2012 Stein Rokkan Lecture: Three decades of populist radical right parties in Western Europe: So what? European Journal of Political Research 52(1): 1-19.

\section{Monographs:}

Akkerman T, De Lange SL and Rooduijn M (2016) Radical Right-Wing Populist Parties in Western Europe: Into the Mainstream? London: Routledge.

Caiani M and Parenti (2013) European and American Extreme Right Groups and the Internet. London: Routledge.

Carter E (2005) The Extreme Right in Western Europe: Success or Failure? Manchester: Manchester University Press.

Givens TE (2005) Voting Radical Right in Western Europe. Cambridge: Cambridge University Press.

Ignazi P (2003) Extreme Right Parties in Western Europe. Oxford: Oxford University Press.

Mudde C (2007) Populist Radical Right Parties. Cambridge: Cambridge University Press.

Rydgren J (ed) (2005) Movements of Exclusion: Radical Right-Wing Populism in the Western World. New York: Nova Publishers.

\section{Classical earlier studies:}

Betz H-G (1994) Radical Right-Wing Populism in Western Europe. New York: St Martin's Press.

Ignazi P (1992) The silent counter revolution. Hypotheses on the emergence of extreme right-wing parties in Europe. European Journal of Political Research 22(1): 3-34.

Kitschelt H and McGann AJ (1995) The Radical Right in Western Europe: A Comparative Analysis. Ann Arbor: University of Michigan Press. 


\section{References}

Aalberg T, Esser F, Reinemann C, Stromback J and De Vreese C (eds) (2016) Populist Political Communication in Europe. New York: Routledge.

Abou-Chadi T (2016) Niche party success and mainstream party policy shifts: How green and radical right parties differ in their impact. British Journal of Political Science 46(2): 417-436.

Abts K and Rummens S (2007) Populism versus democracy. Political Studies 55(2): 405-424.

Akkerman T (2012) Comparing radical right parties in government: Immigration and integration policies in nine countries (1996-2010). West European Politics 35(3): $511-529$

Akkerman T (2015) Immigration policy and electoral competition in Western Europe: A fine-grained analysis of party positions over the past two decades Party Politics 21(1): 54-67.

Akkerman T and De Lange SL (2012) Radical right parties in office: Incumbency records and the electoral cost of governing. Government and Opposition 47(4): 574-596.

Akkerman T and Hagelund A (2007) 'Women and children first!' Anti-immigration parties and gender in Norway and the Netherlands. Patterns of Prejudice 41(2): 197-214.

Akkerman T and Rooduijn M (2015) Pariahs or partners? Inclusion and exclusion of radical right parties and the effects on their policy positions. Political Studies 63(5): 1140-1157.

Akkerman A, Mudde C and Zaslove A (2013) How populist are the people? Measuring populist attitudes in voters. Comparative Political Studies 47(9): 1324-1353.

Akkerman T, De Lange SL and Rooduijn M (2016) Radical Right-Wing Populist Parties in Western Europe: Into the Mainstream? London: Routledge.

Albertazzi D and McDonnell D (2005) The Lega Nord in the second Berlusconi government: In a league of its own. West European Politics 28(5): 952-972.

Albertazzi D and McDonnell D (2010) The Lega Nord back in government. West European Politics 33(6): 1318-1340.

Albertazzi D and McDonnell D (2015) Populists in Power. London: Routledge.

Alessio D and Meredith K (2014) Blackshirts for the twenty-first century? Fascism and the English Defence League. Social Identities 20(1): $104-118$

Allen C (2014) Britain First: The 'frontline resistance' to the Islamification of Britain. The Political Quarterly 85(3): 354-361.

Allen TJ (2015) All in the party family? Comparing far right voters in Western and Post-Communist Europe. Party Politics. Epub ahead of print 8 July 2015. DOI: $10.1177 / 1354068815593457$

Alonso S and Da Fonseca SC (2012) Immigration, left and right. Party Politics 18(6): 865-884.

Andersen JG and Bjørklund T (1990) Structural changes and new cleavages: The Progress Parties in Denmark and Norway. Acta Sociologica 33(3): $195-217$.

Andersen R and Evans JAJ (2003) Social-political context and authoritarian attitudes: Evidence from seven European countries. In: EREPS Annual Meeting, Ghent, 5-7 December.

Art D (2007) Reacting to the radical right: Lessons from Germany and Austria. Party Politics 13(3): $331-349$.

Art D (2011) Inside the Radical Right: The Development of Anti-Immigrant Parties in Europe. Cambridge: Cambridge University Press.

Arzheimer K (2009) Contextual factors and the extreme right vote in Western Europe, 1980-2002. American Journal of Political Science 53(2): 259-275.

Arzheimer K (2012) Electoral sociology: Who votes for the extreme right and why - and when? In: Backes U and Moreau P (eds) The Extreme Right in Europe: Current Trends and Perspectives. Göttingen: Vandenhoeck and Ruprecht, pp. 35-50.

Arzheimer K (2015a) The AfD: Finally a successful right-wing populist Eurosceptic party for Germany? West European Politics 38(3): 535-556.

Arzheimer K (2015b) The AfD's Facebook wall: A new hub for far-right mobilisation in Germany? In: APSA Annual Meeting, San Francisco, 3-6 September.

Arzheimer K and Carter E (2006) Political opportunity structures and right-wing extremist party success. European Journal of Political Research 45(3): 419-443.

Backes U and Moreau P (eds) (2012) The Extreme Right in Europe: Current Trends and Perspectives. Göttingen: Vandenhoeck and Ruprecht.

Bale T (2003) Cinderella and her ugly sisters: The mainstream and extreme right in Europe's bipolarising party systems. West European Politics 26(3): 67-90.

Bale T (2013) More and more restrictive - but not always populist: Explaining variation in the British Conservative Party's stance on immigration and asylum. Journal of Contemporary European Studies 21(1): 25-37.

Bale T, Green-Pedersen C, Krouwel A, Luther KR and Sitter N (2010) If you can't beat them, join them? Explaining Social Democratic responses to the challenge from the populist radical right in Western Europe. Political Studies 58(3): 410-426.

Berning CC and Schlueter E (2016) The dynamics of radical right-wing populist party preferences and perceived group threat: A comparative panel analysis of three competing hypotheses in the Netherlands and Germany. Social Science Research 55: 83-93.

Betz H-G (1994) Radical Right-Wing Populism in 
Western Europe. New York: St Martin's Press.

Betz H-G (2004) Exclusionary populism in Western Europe in the 1990s and beyond: A threat to democracy and civil rights? Identities, Conflict and Cohesion Programme Paper No. 9, United Nations Research Institute for Social Development.

Betz H-G and Johnson C (2004) Against the current - stemming the tide: The nostalgic ideology of the contemporary radical populist right. Journal of Political Ideologies 9(3): 311-327.

Blee KM and Creasap KA (2010) Conservative and right-wing movements. Annual Review of Sociology 36: 269-286.

Boomgaarden HG and Vliegenthart R (2007) Explaining the rise of anti-immigrant parties: The role of news media content. Electoral Studies 26(2): 404-417.

Bohman A (2011) Articulated antipathies: Political influence on anti-immigrant attitudes.

International Journal of Comparative Sociology 52(6): 457-477.

Bohman A and Hjerm M (2016) In the wake of radical right electoral success: A cross-country comparative study of anti-immigration attitudes over time. Journal of Ethnic and Migration Studies 42(11): 1729-1747.

Bos L and Brants K (2014) Populist rhetoric in politics and media: A longitudinal study of the Netherlands. European Journal of Communication 29(6): 703-719.

Bos L, Van der Brug W and De Vreese C (2010) Media coverage of right-wing populist leaders. Communications 35(2): 141-163.

Braun R (2011) The diffusion of racist violence in the Netherlands: Discourse and distance. Journal of Peace Research 48(6): 753-766.

Braun R and Koopmans R (2010) The diffusion of xenophobic violence in Germany: The role of social similarity. European Sociological Review 26(1): $1-25$.

Busher J (2013) Grassroots activism in the English Defence League: Discourse and public (dis)order. In: Taylor M, Currie PM and Holbrook D (eds) Extreme Right-Wing Political Violence and Terrorism. London: Bloomsbury, pp. 65-84.

Caiani M and Borri R (2013) The extreme right, violence and other action repertoires: An empirical study on two European countries. Perspectives on European Politics and Society 14(4): 562-581.

Caiani M and Della Porta D (2011) The elitist populism of the extreme right: A frame analysis of extreme right-wing discourses in Italy and Germany. Acta Politica 46(2): 180-202.

Caiani M and Parenti L (2013) European and American Extreme Right Groups and the Internet. London: Routledge.

Caiani M, Della Porta D, and Wagemann C (2012) Mobilizing on the Extreme Right: Germany, Italy, and the United States. Oxford: Oxford University Press.

Canovan M (1999) Trust the people! Populism and the two faces of democracy. Political Studies 47(1): 2-16.

Carter EL (2002) Proportional representation and the fortunes of right-wing extremist parties. West European Politics 25(3): 125-146.

Carter E (2005) The Extreme Right in Western Europe: Success or Failure? Manchester: Manchester University Press.

Castells M (1997) The Information Age: Economy, Society and Culture. Vol. 2, The Power of Identity. London: Blackwell.

Clarke H, Whiteley P, Borges W, Sanders D and Stewart M (2016) Modelling the dynamics of support for a right-wing populist party: The case of UKIP. Journal of Elections, Public Opinion and Parties 26(2): 135-154.

Coffé H (2005) Do individual factors explain the different success of the two Belgian extreme right parties. Acta Politica 40(1): 74-93.

Deiwiks C (2009) Populism. Living Reviews in Democracy, Vol. 1. Available at: http://idwebhost-20283.ethz.ch/index.php/lrd/article/view/lrd-20093/11 (accessed 20 November 2016).

De Koster W, Achterberg P, Van der Waal J, Van Bohemen $S$ and Kemmers R (2014) Progressiveness and the new right: The electoral relevance of culturally progressive values in the Netherlands. West European Politics 37(3): 584-604.

De Lange SL (2007) A new winning formula? The programmatic appeal of the radical right. Party Politics 13(4): 411-435.

De Lange SL (2012) Radical right-wing populist parties in offices: A cross-national comparison. In: Backes U and Moreau P (eds) The Extreme Right in Europe: Current Trends and Perspectives. Göttingen: Vandenhoeck and Ruprecht, pp. 171-194.

De Lange SL and Akkerman T (2012) Populist parties in Belgium: A case of hegemonic liberal democracy? In: Mudde C and Rovira Kaltwasser C (eds) Populism in Europe and the Americas: Threat or Corrective for Democracy? New York: Cambridge University Press, pp. 27-45.

De Lange SL and Art D (2011) Fortuyn versus Wilders: An agency-based approach to radical right party building. West European Politics 34(6): 1229-1249.

De Witte H and Klandermans B (2000) Political racism in Flanders and the Netherlands: Explaining differences in the electoral success of extreme right-wing parties. Journal of Ethnic and Migration Studies 26(4): 699-717.

Dunn K (2015) Preference for radical right-wing populist parties among exclusive-nationalists and authoritarians. Party Politics 21(3): 367-380.

Dunn KP and Singh SP (2011) The surprising non-impact of radical right-wing populist party 
representation on public tolerance of minorities. Journal of Elections, Public Opinion and Parties 21(3): 313-331.

Eatwell R (2000) The rebirth of the 'extreme right' in Western Europe? Parliamentary Affairs 53(3): $407-425$.

Eatwell R (2005) Charisma and the revival of the European extreme right. In: Rydgren J (ed.) Movements of Exclusion: Radical Right-Wing Populism in the Western World. New York: Nova Publishers, pp. 101-120.

Eger MA and Valdez S (2015) Neo-nationalism in Western Europe. European Sociological Review 31(1): 115-130.

Ellinas AA (2007) Phased out: Far right parties in Western Europe. Comparative Politics 39(3): 353-371.

Ellinas AA (2009) Chaotic but popular? Extremeright organisation and performance in the age of media communication. Journal of Contemporary European Studies 17(2): 209-221.

Erk J (2005) From Vlaams Blok to Vlaams Belang: The Belgian far-right renames itself. West European Politics 28(3): 493-502.

Fallend F (2012) Populism in government: The case of Austria. In: Mudde C and Rovira Kaltwasser C (eds) Populism in Europe and the Americas: Threat or Corrective for Democracy? New York: Cambridge University Press, pp. 113-135.

Fennema M (1997) Some conceptual issues and problems in the comparison of anti-immigrant parties in Western Europe. Party Politics 3(4): 473-492.

Ford R and Goodwin MJ (2014) Revolt on the Right: Explaining Support for the Radical Right in Britain. London: Routledge.

Franklin MN (2004) Voter Turnout and the Dynamics of Electoral Competition in Established Democracies since 1945. Cambridge: Cambridge University Press.

Frölich-Steffen S and Rensmann L (2007) Conditions for failure and success of right-wing populist parties. In: Delwit P and Poirier P (eds) Extreme Droite et Pouvoir en Europe. Brussels: Université de Bruxelles, pp. 117-141.

Gamson WA and Wolfsfeld G (1993) Movements and media as interacting systems. The Annals of the American Academy of Political and Social Science 528: 114-125.

Geiges L, Marg S and Walter F (2015) Pegida. Die schmutzige Seite der Zivilgesellschaft. Bielefeld: Transcript Verlag.

Gidron N and Bonikowski B (2013) Varieties of populism: Literature review and research agenda. Working Paper Series Weatherhead Center for International Affairs, No.13-0004, Harvard University.

Giugni M, Koopmans R, Passy F and Statham P (2005) Institutional and discursive opportunities for extreme-right mobilization in five countries. Mobilization: An International Quarterly 10(1):
$145-162$.

Givens TE (2005) Voting Radical Right in Western Europe. Cambridge: Cambridge University Press.

Godin E (2013) The porosity between the mainstream right and extreme right in France: Les droites décomplexées under Nicolas Sarkozy and Marine Le Pen's leadership. Journal of Contemporary European Studies 21(1): 53-67.

Golder M (2003) Explaining variation in the success of extreme right parties in Western Europe. Comparative Political Studies 36(4): 432-466.

Goodwin MJ (2006) The rise and faults of the internalist perspective in extreme right studies. Representation 42(4): 347-364.

Hakhverdian A and Koop C (2007) Consensus democracy and support for populist parties in Western Europe. Acta Politica 42(4): 401-420

Han KJ (2014) The impact of radical right-wing parties on the positions of mainstream parties regarding multiculturalism. West European Politics 38(3): 1-20.

Heinisch R (2003) Success in opposition-failure in government: Explaining the performance of right-wing populist parties in public office. West European Politics 26(3): 91-130.

Heinisch R and Mazzoleni O (eds) (2016) Understanding Populist Party Organisation: The Radical Right in Western Europe. London: Palgrave Macmillan.

Helbling M and Tresch A (2011) Measuring party positions and issue salience from media coverage: Discussing and cross-validating new indicators. Electoral Studies 30(1): 174-183.

Hooghe L, Bakker R, Brigevich A et al. (2010) Reliability and validity of measuring party positions: The Chapel Hill Expert Surveys of 2002 and 2006. European Journal of Political Research 49(5): 684-703.

Hutter S (2014) Protesting Culture and Economics in Western Europe: New Cleavages in Left and Right Politics. Minneapolis: University of Minnesota Press.

Hutter S and Kriesi H (2013) Movements of the left, movements of the right reconsidered. In: Van Stekelenburg J, Roggeband C and Klandermans B (eds) The Future of Social Movement Research. Minneapolis: University of Minnesota Press, pp. 281-298.

Ignazi P (2003) Extreme Right Parties in Western Europe. Oxford: Oxford University Press.

Immerzeel T (2015) Voting for a change: The democratic lure of populist radical right parties in voting behavior. PhD dissertation, Utrecht University, the Netherlands.

Immerzeel T and Pickup M (2015) Populist radical right parties mobilizing 'the people'? The role of populist radical right success in voter turnout. Electoral Studies 40: 347-360.

Immerzeel T, Lubbers M, and Coffé H (2011) Expert Judgment Survey for European Political 
Parties. Utrecht: Utrecht University. Archived at DANS:

https://easy.dans.knaw.nl/ui/datasets/id/easydataset:55725: NWO, Department of Sociology.

Immerzeel T, Lubbers $M$ and Coffé $H$ (2016) Competing with the radical right: Distances between the European radical right and other parties on typical radical right issues. Party Politics 22(6): 823-834.

Inglehart R and Norris P (2016) Trump, Brexit, and the rise of populism: Economic have-nots and cultural backlash. HKS Working Paper No. RWP16-026, Harvard University.

Ivarsflaten E (2005) Threatened by diversity: Why restrictive asylum and immigration policies appeal to Western Europeans. Journal of Elections, Public Opinion and Parties 15(1): 21-45.

Ivarsflaten E (2008) What unites right-wing populists in Western Europe? Re-examining grievance mobilization models in seven successful cases. Comparative Political Studies 41(1): 3-23.

Jackman RW and Volpert K (1996) Conditions favouring parties of the extreme right in Western Europe. British Journal of Political Science 26(4): 501-521.

Jagers J and Walgrave S (2007) Populism as political communication style: An empirical study of political parties' discourse in Belgium. European Journal of Political Research 46(3): 319-345.

Jansen RS (2011) Populist mobilization: A new theoretical approach to populism. Sociological Theory 29(2): 75-96.

John P and Margetts H (2009) The latent support for the extreme right in British politics. West European Politics 32(3): 496-513.

Kitschelt H (2004) Diversification and Reconfiguration of Party Systems in Postindustrial Democracies. Bonn: Friedrich Ebert Stiftung.

Kitschelt H (2007) Growth and persistence of the radical right in postindustrial democracies: Advances and challenges in comparative research. West European Politics 30(5): 1176-1206.

Kitschelt H and McGann AJ (1995) The Radical Right in Western Europe: A Comparative Analysis. Ann Arbor: University of Michigan Press.

Klandermans B (2004) The demand and supply of participation: Social-psychological correlates of participation in social movements. In: Snow DA, Soule SA and Kriesi H (eds) The Blackwell Companion to Social Movements. Malden, MA: Blackwell, pp. 360-379.

Klandermans B and Mayer N (eds) (2006) Extreme Right Activists in Europe: Through the Magnifying Glass. London: Routledge.

Koopmans R (1996) Explaining the rise of racist and extreme right violence in Western Europe: Grievances or opportunities? European Journal of
Political Research 30(2): 185-216.

Koopmans R and Muis J (2009) The rise of rightwing populist Pim Fortuyn in the Netherlands: A discursive opportunity approach. European Journal of Political Research 48(5): 642-664.

Koopmans R and Olzak S (2004) Discursive opportunities and the evolution of right-wing violence in Germany. American Journal of Sociology 110(1): 198-230.

Koopmans R, Statham P, Giugni M and Passy F (2005) Contested Citizenship: Immigration and Cultural Diversity in Europe. Minneapolis: University of Minnesota Press.

Kriesi H, Grande E, Lachat R, Dolezal M, Bornschier S and Frey T (2006) Globalization and the transformation of the national political space: Six European countries compared. European Journal of Political Research 45(6): 921-956.

Kriesi H, Grande E, Lachat R, Dolezal M, Bornschier S and Frey T (2008) West European Politics in the Age of Globalization. Cambridge: Cambridge University Press.

Kriesi H, Grande E, Dolezal M et al. (2012) Political Conflict in Western Europe. Cambridge: Cambridge University Press.

Laver M and Sergenti E (2012) Party Competition: An Agent-Based Model. Princeton, NJ: Princeton University Press.

Lubbers M (2001) Exclusionistic electorates: Extreme right-wing voting in Western Europe. Doctoral dissertation, Radboud University Nijmegen, the Netherlands.

Lubbers M and Scheepers P (2000) Individual and contextual characteristics of the German extreme right-wing vote in the 1990s: A test of complementary theories. European Journal of Political Research 38(1): 63-94.

Lubbers M and Scheepers P (2001) Explaining the trend in extreme right-wing voting: Germany 1989-1998. European Sociological Review 17(4): 431-449.

Lubbers M, Gijsberts M and Scheepers P (2002) Extreme right-wing voting in Western Europe. European Journal of Political Research 41(3): 345-378.

Luther KR (2011) Of goals and own goals: A case study of right-wing populist party strategy for and during incumbency. Party Politics 17(4): 453-470.

Mazzoleni G (2008) Populism and the media. In: Albertazzi D and McDonnell (eds) Twenty-First Century Populism. Basingstoke: Palgrave Macmillan, pp. 49-64

Meguid BM (2005) Competition between unequals: The role of mainstream party strategy in niche party success. American Political Science Review 99(3): 347-359.

Meguid BM (2008) Party Competition Between Unequals: Strategies and Electoral Fortunes in Western Europe. Cambridge: Cambridge 
University Press.

Minkenberg M (2000) The renewal of the radical right: Between modernity and anti modernity. Government and Opposition 35(2): 170-188.

Minkenberg M (2005) From party to movement? The German radical right in transition. In: Casals X (ed.) Political Survival on the Extreme Right: European movements Between the Inherited Past and the Need to Adapt to the Future. Barcelona: ICPS, pp. 51-70.

Minkenberg M (2011) The radical right in Europe today: Trends and patterns in East and West. In: Langenbacher $\mathrm{N}$ and Schellenberg B (eds) Is Europe on the 'Right' Path? Berlin: FriedrichEbert-Stiftung, pp. 37-55.

Minkenberg M (ed.) (2015) Transforming the Transformation? The East European Radical Right in the Political Process. New York: Routledge.

Mouffe C (2005) The 'end of politics' and the challenge of right-wing populism. In: Panizza F (ed.) Populism and the Mirror of Democracy. London: Verso, pp. 50-71.

Mudde C (2007) Populist Radical Right Parties. Cambridge: Cambridge University Press.

Mudde C (2010) The populist radical right: A pathological normalcy. West European Politics 33(6): 1167-1186

Mudde C (2013) The 2012 Stein Rokkan Lecture: Three decades of populist radical right parties in Western Europe: So what? European Journal of Political Research 52(1): 1-19.

Mudde C (2014) Fighting the system? Populist radical right parties and party system change. Party Politics 20(2): 217-226.

Mudde C and Rovira Kaltwasser C (eds) (2012) Populism in Europe and the Americas: Threat or Corrective for Democracy? New York: Cambridge University Press.

Muis J (2015) The rise and demise of the Dutch extreme right: Discursive opportunities and support for the Center Democrats in the 1990s. Mobilization: An International Quarterly 20(1): 41-60.

Muis J and Scholte M (2013) How to find the 'winning formula'? Conducting simulation experiments to grasp the tactical moves and fortunes of populist radical right parties. Acta Politica 48(1): 22-46.

Norris P (2005) Radical Right: Voters and Parties in the Electoral Market. New York: Cambridge University Press.

Oesch D (2008) Explaining workers' support for right-wing populist parties in Western Europe: Evidence from Austria, Belgium, France, Norway, and Switzerland. International Political Science Review 29(3): 349-373.

Parker CS and Barreto MA (2014) Change They Can't Believe in: The Tea Party and Reactionary Politics in America. Princeton, NJ: Princeton University Press.

Patzelt WJ and Klose J (eds) (2016) PEGIDA.
Warnsignale aus Dresden. Dresden: Thelem Universitätsverlag.

Pauwels T (2011a) Measuring populism: A quantitative text analysis of party literature in Belgium. Journal of Elections, Public Opinion and Parties 21(1): 97-119.

Pauwels T (2011b) Explaining the strange decline of the populist radical right Vlaams Belang in Belgium: The impact of permanent opposition. Acta Politica 46(1): 60-82.

Pelinka A (2013) Right-wing populism: Concept and typology. In: Wodak R, KhosravNik M and Mral B (eds) Right-Wing Populism in Europe: Politics and Discourse. London: Bloomsbury, pp. 3-22.

Pirro A (2015) The Populist Radical Right in Central and Eastern Europe: Ideology, Impact, and Electoral Performance. London: Routledge.

Plasser F and Ulram PA (2003) Striking a responsive chord: Mass media and right-wing populism in Austria. In: Mazzoleni G, Stewart J and Horsfield B (eds) The Media and NeoPopulism: A Comparative Analysis. Westport, CT: Praeger, pp. 21-43.

Ravndal JA (2016) Right-wing terrorism and violence in Western Europe: Introducing the RTV dataset. Perspectives on Terrorism 10(3). Available at: www.terrorismanalysts.com/pt/index.php/pot/ar ticle/view/508/html (accessed 27 November 2016).

Reuband KH (2015) Wer demonstriert in Dresden für Pegida? Ergebnisse empirischer Studien, methodische Grundlagen und offene Fragen. Mitteilungen des Instituts für Parteienrecht und Parteienforschung 21: 133-143.

Rooduijn M (2014) The mesmerising message: The diffusion of populism in public debates in Western European media. Political Studies 62(4): 726-744.

Rooduijn M and Pauwels T (2011) Measuring populism: Comparing two methods of content analysis. West European Politics 34(6): 1272-1283.

Rooduijn M, De Lange SL and Van Der Brug W (2014) A populist Zeitgeist? Programmatic contagion by populist parties in Western Europe. Party Politics 20(4): 563-575.

Rooduijn M, Van der Brug W and De Lange SL (2016) Expressing or fuelling discontent? The relationship between populist voting and political discontent. Electoral Studies 43: 32-40.

Rosanvallon P (2008) Counter-Democracy: Politics in an Age of Distrust. New York: Cambridge University Press.

Rydgren J (ed.) (2005a) Movements of Exclusion: Radical Right-Wing Populism in the Western World. New York: Nova Publishers.

Rydgren J (2005b) Is extreme right wing populism contagious? Explaining the emergence of a new party family. European Journal of Political 
Research 44(3): 413-437.

Rydgren J (2007) The sociology of the radical right. Annual Review of Sociology 33(1): 241-262.

Rydgren J (2013) Introduction: Class politics and the radical right. In: Rydgren J (ed.) Class Politics and the Radical Right. London: Routledge, pp. 1-9.

Schain MA (2006) The extreme-right and immigration policy-making: Measuring direct and indirect effects. West European Politics 29(2): 270-289.

Schumacher G and Van Kersbergen K (2016) Do mainstream parties adapt to the welfare chauvinism of populist parties? Party Politics 22(3): 300-312.

Semyonov M, Raijman R and Gorodzeisky A (2006) The rise of anti-foreigner sentiment in European societies, 1988-2000. American Sociological Review 71(3): 426-449.

Sprague-Jones J (2011) Extreme right-wing vote and support for multiculturalism in Europe. Ethnic and Racial Studies 34(4): 535-555.

Stewart J, Mazzoleni G and Horsfield B (2003) Conclusion: Power to the media managers. In: Mazzoleni G, Stewart J and Horsfield B (eds) The Media and Neo-Populism: A Comparative Analysis. Westport, CT: Praeger, pp. 217-237.

Swank D and Betz H-G (2003) Globalization, the welfare state and right-wing populism in Western Europe. Socio-Economic Review 1(2): 215-245.

Swyngedouw M (2001) The subjective cognitive and affective map of extreme right voters: Using open-ended questions in exit polls. Electoral Studies 20(2): 217-241.

Tavits M (2006) Party system change testing a model of new party entry. Party Politics 12(1): 99-119.

Usherwood S and Startin N (2013) Euroscepticism as a persistent phenomenon. Journal of Common Market Studies 51(1): 1-16.

Van der Brug W (2003) How the LPF fuelled discontent: Empirical tests of explanations of LPF support. Acta Politica 38(1): 89-106.

Van der Brug W and Fennema M (2007) Causes of voting for the radical right. International Journal of Public Opinion Research 19(4): 474-487.

Van der Brug W and Mughan A (2007) Charisma, leader effects and support for right-wing populist parties. Party Politics 13(1): 29-51.

Van der Brug W, Fennema M and Tillie J (2000) Anti immigrant parties in Europe: Ideological or protest vote? European Journal of Political Research 37(1): 77-102.

Van der Brug W, Fennema M and Tillie J (2005) Why some anti-immigrant parties fail and others succeed. Comparative Political Studies 38(5): 537-573.

Van der Meer TWG, Van Deth JW and Scheepers PLH (2009) The politicized participant: Ideology and political action in 20 democracies.
Comparative Political Studies 42(11): 1426-1457.

Van der Pas D, De Vries C and Van der Brug W (2013) A leader without a party: Exploring the relationship between Geert Wilders' leadership performance in the media and his electoral success. Party Politics 19(3): 458-476.

Van Heerden S, De Lange SL, Van der Brug W and Fennema M (2014) The immigration and integration debate in the Netherlands: Discursive and programmatic reactions to the rise of anti-immigration parties. Journal of Ethnic and Migration Studies 40(1): 119-136.

Van Kessel S (2015) Populist Parties in Europe: Agents of Discontent? Basingstoke: Palgrave Macmillan.

Van Kessel S and Castelein R (2016) Shifting the blame: Populist politicians' use of Twitter as a tool of opposition. Journal of Contemporary European Research 12(2): 594-614.

Van Spanje J (2010) Contagious parties: Antiimmigration parties and their impact on other parties immigration stances in contemporary Western Europe. Party Politics 16(5): 563-586.

Van Spanje J (2011a) The wrong and the right: A comparative analysis of 'anti-immigration' and 'far right' parties. Government and Opposition 46(3): 293-320.

Van Spanje J (2011b) Keeping the rascals in: Antipolitical-establishment parties and their cost of governing in established democracies. European Journal of Political Research 50(5): 609-635.

Van Spanje J and De Vreese C (2015) The good, the bad and the voter: The impact of hate speech prosecution of a politician on electoral support for his party. Party Politics 21(1): 115-130.

Van Spanje J and Van der Brug W (2009) Being intolerant of the intolerant: The exclusion of Western European anti-immigration parties and its consequences for party choice. Acta Politica 44(4): 353-384.

Veugelers J and Magnan A (2005) Conditions of far right strength in contemporary Western Europe: An application of Kitschelt's theory. European Journal of Political Research 44(6): 837-860.

Vliegenthart R, Boomgaarden HG and Van Spanje J (2012) Anti-immigrant party support and media visibility: A cross-party, over-time perspective. Journal of Elections, Public Opinion and Parties 22(3): 315-358.

Walgrave S and De Swert K (2004) The making of the (issues of the) Vlaams Blok. Political Communication 21(4): 479-500.

Weber M (1947 [1921]) Theory of Social and Economic Organization, trans. T Parsons. New York: Oxford University Press.

Wilkes R, Guppy N and Farris L (2007) Rightwing parties and anti-foreigner sentiment in Europe. American Sociological Review 72(5): 
831-840.

Williams MH (2006) The Impact of Radical Right-

Wing Parties in West European Democracies. New York: Palgrave Macmillan.

Williamson V, Skocpol T and Coggin J (2011) The Tea Party and the remaking of Republican conservatism. Perspectives on Politics 9(1): 25-43.

Yilmaz F (2012) Right-wing hegemony and immigration: How the populist far-right achieved hegemony through the immigration debate in Europe. Current Sociology 60(3) 368-381.
Zaslove A (2004) Closing the door? The ideology and impact of radical right populism on immigration policy in Austria and Italy. Journal of Political Ideologies 9(1): 99-118.

Zaslove A (2008) Here to stay? Populism as a new party type. European Review 16(3): 319-336.

Zhirkov K (2014) Nativist but not alienated: A comparative perspective on the radical right vote in Western Europe. Party Politics 20(2): 286-296.

Jasper Muis is Assistant Professor at the Sociology Department of the VU University Amsterdam, the Netherlands. His research interests include right-wing populism, protest behaviour, political communication and complex adaptive systems. His dissertation, titled 'Pim Fortuyn: The evolution of a media phenomenon' about the breakthrough of right-wing populism in the Netherlands, received the Dutch Research Prize of the Praemium Erasmianum Foundation.

Tim Immerzeel is a teacher in social studies in the city of Rotterdam - the stronghold of Pim Fortuyn's party. He was postdoctoral research fellow at the Department of Sociology at VU University Amsterdam and member of the international PolPart project team that investigates why people participate in politics. He finished his dissertation at the Department of Sociology/ICS at Utrecht University, the Netherlands. It investigates the relationship between political participation and radical right-wing voting, and examines the mobilization success of radical right parties.

résumé Cet article analyse trois points parmi les connaissances actuelles sur la droite radicale et populiste en Europe occidentale. Nous évaluons tout d'abord les explications sur l'opportunité politique de la réussite de la droite radicale et populiste. Nous traitons ensuite des approches de l'offre interne, en nous référant au leadership, à l'organisation et au positionnement idéologique. Enfin, nous examinons la recherche sur les conséquences de la montée de ces partis et mouvements : constituent-ils une correction ou une menace pour la démocratie ? Pour conclure, cet article propose de nouvelles pistes de théorisation et de recherche.

mots-clés droite radicale extrême droite partis/mouvements anti-immigration $\bullet$ populisme

resumen En este artículo se revisan tres vertientes de la investigación sobre la derecha radical populista (DRP) en Europa Occidental. En primer lugar, se evalúan las explicaciones de oportunidad política para las fortunas de la DRP. En segundo lugar, se comentan los enfoques internos centrados en la oferta en relación con el liderazgo, la organización y el posicionamiento ideológico. En tercer lugar, se analizan las investigaciones sobre las consecuencias del auge de dichos partidos y movimientos: ¿constituyen un correctivo o una amenaza para la democracia? La revisión concluye con la exposición de futuras vías de teorización e investigación.

palabras clave derecha radical $\bullet$ extrema derecha $\bullet$ partidos/movimientos antiinmigración populismo 